\title{
Investigation on production constraints and adoption of inorganic insecticides and spraying regime in management of cowpea (Vigna uncuiculata L. Walp) insects in Mubi zone, Nigeria
}

\author{
Sabo, Elizabeth ${ }^{1,2 \star}$, Bashir, R. M. ${ }^{1}$, Gidado, A. S. ${ }^{1}$, Sani, R. M. ${ }^{2}$ and Adeniji, O. T. ${ }^{3}$ \\ ${ }^{1}$ School of Science and Technology, National Open University of Nigeria, Nigeria. \\ ${ }^{2}$ Department of Agricultural Economics and Extension, Abubakar Tafawa Balewa University, Nigeria. \\ ${ }^{3}$ Department of Crop Science, Adamawa State University, Adamawa State, Nigeria.
}

Accepted 4 November, 2013

\begin{abstract}
Between 2008 and 2009, constraints in cowpea cultivation and adoption of inorganic insecticides in insect pest management were investigated among cowpea producers in Mubi zone of Adamawa State. Structured questionnaires were used to source for information from 611 respondents, who were randomly selected. The Chi-square test, Likert scale test and logistic regression method were used to analyze the data set. Preference was high for using inorganic insecticides, spraying time and regime and seed treatment. Production constrains in the study area were insect pests attack and diseases and high cost of inorganic insecticides. The use of insecticides (100\%) and practice of spraying regime $(99 \%)$ were high. High adoption rate as found for use of inorganic insecticides and spraying regime were traceable to awareness that non use of insecticides at the appropriate time will account for low seed yield and crop failure. Adoption of inorganic insecticides was related to age $(\beta=0.09, P<0.01)$, educational attainment $(\beta=0.98, P<0.05)$, membership of socio-cultural organization $(\beta=1.27, P<0.01)$, land preparation methods $(\beta=-1.40, P<0.001)$ and consideration for the dealers during purchase of inorganic insecticides $(\beta=0.92, P<0.001)$. Similarly, adoption was high for practice of spraying regime for inorganic insecticides. Misuse of inorganic insecticides was prevalent among farmers in Mubi zone. The study recommends introduction and promotion of resistant varieties biopesticides and other environmentally safe and less injurious insect pests' management techniques.
\end{abstract}

Key words: Nigeria, Mubi zone, adoption, extension service, inorganic insecticides, insect pests' management, cowpea farmers'.

\section{INTRODUCTION}

Information available from FAO (1998) indicated that cowpea is cultivated on at least 12.5 million ha, with annual production of over 3 million tons worldwide. It is widely distributed throughout the tropics, but Central and West Africa accounts for $64 \%$ of the area (with 8 million ha), followed by 2.4 million ha in East and Southern Africa. To a lesser extent, some cowpea is cultivated in the Middle East and southern Europe. The important cowpea growing countries are Nigeria, Niger Republic, Mali, Burkina Faso, Senegal, Ghana, Togo, Benin, 
Cameroon, Chad in West and Central Africa: Sudan, Somalia, Kenya, Malawi, Uganda, Tanzania, Zambia, Zimbabwe, Botswana, and Mozambique in East and southern Africa. Most of the total world production of cowpea is in Nigeria, Burkina Faso, Uganda, Niger and Senegal (Rachie, 1985). Although, cowpea can survive on a wide range of soils, the highest yields are obtained on well drained soils with medium fertility (FAO, 1998). Cowpea is adapted to warm weather, drought tolerant crop with better growth in warm climates, and requires less rainfall than most crops. It is the most popular in semi arid regions of the tropics, where other food legumes do not perform as well (Rachie, 1985). Different types of cowpea have been developed and released by research. There are the early maturing types (60 to 70 days), medium maturing (75 to 90 days), late maturing (85 to 120 days). Also, varieties grown by farmers are categorized based on whether they are erect or spreading types, their economic use as fodder and grain types. In addition, there are cowpea varieties with white, brown or red seed coat colour; also, they vary in seed size and cooking time (Rachie, 1985).

A number of constraints adversely affect cowpea production and marketing in sub Sahara Africa. These includes among others non availability of market preferred varieties, low yield, pest and disease problems, high cost of farmland preparation, lack of improve tools, socio-economic factors, high cost and absence of labour, high cost of pesticides and adulteration, hazard to the farmers and environment, poor pricing and marketing channels. All these factors affect production and income directly or indirectly. A major problem in cowpea production is the menace by insect pests. Currently, economic necessity and environmental destruction have rendered insecticide use socially unacceptable, although somewhat unrealistically so. In addition, there is increased advocacy for monitored rather than calendarbased insecticides application, if insecticides must be used (Jack and Daoust, 1986). Getting a good crop stand is paramount to getting good yield. Damage from insects as beetles, bean fly, can cause poor stand. One way this can be avoided is by treating the seeds with insecticides dust or slurry before they are planted. Jackai et al. (1985) noted that seed treatment of about $10 \mathrm{~g} / \mathrm{kg}$ of Marshal at (carbosulfan) protect cowpea seedling from aphids, foliage beetles and herbivore such as bean fly for up to three weeks in the screen house, and for longer periods under field conditions. More recently, another seed dressing chemical, Apron plus, Fernasan D (25\% Thiram $+20 \%$ Lindane) have been introduced and adopted by farmers.

The potential negative environmental impacts of modern agricultural practices (including insecticide use) have been long recognized as a major health concerns. There are no precise and official estimates of pesticides use in Nigeria. There are many techniques or practices collectively referred to as Integrated Pests Management
(IPM) that have been designed to address some of the health and environmental concerns of pesticide use and the problem of pests' resistance to pesticides. IPM is a management approach by anticipating pests' problems and preventing pests' from reaching economically damaging levels. All appropriate techniques are used such as enhancing natural enemies, planting resistant varieties and using pesticides judiciously while the IPM emphasizes minimal use of insecticides in controlling pests, their adoption by farmers can reduce the use of insecticides and their adverse impacts (Jackai et al., 1993). Generally, researchers and extension agents are often frustrated by slower rate than expected of adoption levels. Slow rate of adoption causes a loss of potential benefit of sustainable practices to growers and the public.

The use of plant extracts for example neem (Azadiracta indica) is very popular, but its effect on pests and seed yield is not available. In addition, this technology (plant extract) has not been commercialized in sub Sahara Africa; hence the high dependent on inorganic insecticides. Information on awareness of cowpea insect pests' management technologies in cowpea is limited compared to available information in maize and cassava. This trend may be associated with assumption that cowpea can successfully be cultivated with the use of insecticides, and that other technologies developed by research are not available. However, Agwu (2001) reported comparative advantages offered by the use of improved cowpea technologies to acceptance and use of technologies by cowpea farmers to boost cowpea production, and acceptance of these technologies vary and has been far from encouraging. In another study, Agwu (2004) noted high awareness for the use of inorganic insecticides as compared to other insect pests control methods commonly used in the control of insects on cowpea plants among cowpea farmers in Bauchi and Gombe states, Nigeria. In addition, spacing technique (75 $\times 25$ to $30 \mathrm{~cm}$ ), fungicides, fertilizer and herbicides recorded low adoption and awareness among farmers in Nigeria (Agwu, 2004).

Various factors affect the adoption models; these include willingness to adopt a technology, access to labour, capital, and informational affect decision. Also, available literature shows that many factors do influence adoption of innovations of any kind. These factors could be measured using various models. The commonly used ones are logit, probit and tobit which all have equal applications (Gujarati, 1995). The models are also known as dichotomous (having a numerical value greater than 1) or binary (having a numerical value either 0 or 1 ) (Tobin, 1958; Wooldridge, 2001). The advantage of these models is that they can determine the impact of socio-economic parameters in relation to other factors (Amemiya, 1981). Empirically, Tobit, Logit and Probit models give similar results (Gujarati, 1995). The logit model operates in the form of simple least squares. Agriculture serves as a major employer of labour in Mubi zone, Nigeria where 
farming is largely subsistence and most farmers were non-illiterate and are resource constrained. Cowpea production is limited by an array of agronomic (poor soil fertility, high cost of land preparation etc), socio economic (sex, age, education etc) and institutional (farm size, membership of social organization etc) constraints (Alghali, 1991). These have negatively impacted on crop growth, yield and livelihood.

The preponderance of cowpea insects on farmers' fields causes huge yield losses in most cases grain yield less than $10 \mathrm{~kg}$ are obtained on farmers' fields (Jackai et al., 1985). In addition, high cost of insecticides, adulteration and misuse of insecticides are challenges which are as old as cowpea farming. These have greatly contributed negatively to yield obtained on farmers' field. On the other hand, cowpea farmers require high capital for purchase of seeds, agrochemicals and payment of labour, these makes cowpea production very complex and not interesting. The extension services have not been able to disseminate and impact to cowpea farmers in this zone, the recommended integrated pests' management practices, which emphasize the use of resistant varieties alongside complementary practices (Adamawa State Extension Service, 1990). At present, farmers are not adopting this all important agronomic and integrated approaches designed for insect pest management. This may be due to the complexity of the technology or inadequate on - farm demonstration and dissemination (Ajala, 1992). Therefore, it is imperative to understand awareness level of insect pests' management techniques by cowpea farmers, how socio-economic, institutional, demographic variables and agronomic practices influence awareness and adoption of insect pests' management techniques.

Further, how effective are these insect pests' management techniques among cowpea producers in Mubi zone, Nigeria. However, it is important to understand if insecticides are being sprayed by farmers at a recommended dose or over dosed. Either of these conditions poses a serious health hazard to the farmers and the communities and degradation of the soil and environment. There is inadequate information on awareness, adoption and determinants of adoption of information technology in the study area; hence, the need for this research.

\section{METHODOLOGY}

A multistage sampling procedure was adopted for this study, five local government areas, which constitute Mubi zone was purposively selected because farmers in Mubi zone are largely involved in cowpea production. Two districts each from each LGA namely Michika and Bazza (Michika Local Government Area), Muchala and Mubi (Mubi North Local Government) Maiha and Pakka (Maiha Local Government), Gulak and Shuwa (Madagali Local Government Areas) and Mugulvu and Gella (Mubi South Local Government) were purposively selected due to preponderance of cowpea cultivation activities and population density. Thereafter, two villages were selected at random from each district Muchala (Mayo bani and Muva), Mubi (Batonde and Mukta), Michika (Watu and Lughe), Bazza (Kudzum and Likuni), Maiha (Bwade and Cede), Pakka (Dafra and Duhu), Gulak (Sukur and Duhu) and Shuwa (Mayowanda and Gubla). Proportionate sampling of farmers was undertaken to select 700 farmers from the 10 districts, and 20 villages based on their population. For the purpose of this study, both primary and secondary data were used, the questionnaire was the source of the primary data. Of the 700 questionnaires administered over two years, 611 were returned and thus constituted the sampling size and were processed for data analysis. For each village, 20 cowpea farmers were randomly selected to provide information on the cowpea production activities and adoption of insect pests' management technologies.

The survey took place through August 2008 and December 2009 cowpea cropping season. Questionnaires were administered by the researcher alongside some assistants from the ADP staff.

\section{Data collection and computation}

Data collected from the respondents cover demographic, economic and institutional variables, these variables are age (years), sex, occupation and experience (years) in cowpea production, educational attainment, farm size, household size and marital status, experience in cowpea production (years), access to loan and frequency of extension contacts among others. Also, information on quantity of seed planted/hectare, seed source, land preparation methods, presence and absence of extension agents and extension meeting etc were sought from cowpea producers. Data collected over years of evaluation were summarized, pooled and subjected to descriptive statistics as mean, frequency distribution, percentages and Chi-square 'goodness - of - fit' test, to determine if the frequency distribution of the categories observed for socio-economic, institutional and production variables differ or are similar. The constraints to cowpea production were sourced through focus group discussion approach, farmers made their responses independent of the other farmers. Similarly, the extent to which sociological, economic and institutional variables hinder cowpea production in Mubi zone were sought from cowpea producers.

For both cases, data collected were analyzed using a four point Likert rating scale (LRS), as great extent $=4$, some extent $=3$, little extent $=2$, no extent $=1$. The mean score was computed as $4+3+$ $2+1=10 / 4=2.50$. Using the interval score of 0.05 , the upper limit cut-off was determined as $2.50 \pm 0.05$ and the lower limit as $2.55 \pm$ $0.05=2.45$. On the basis of this, mean score (MS) below 2.45 (that is, <2.45) were ranked 'low', those between 2.45 and 2.54 were considered 'medium' (that is, $2.45 \geq \mathrm{MS} \leq 2.54$ ), while the mean score greater than or equal to 2.55 (that is, $M S \geq 2.55$ ) were considered 'high'. Adoption studies typically use various types of the logistic models to analyze survey data. The models recognized adoption as a dependent categorical variable. Linear regression is inappropriate method for adoption studies for several reasons. In the case of adoption, the dependent variable takes a limited number of values and the error term is not normally distributed. Binary response models (logit) are used where adoption is considered as Yes or No decision by farmers. The probability of adopting technology is either 1 (for adopters) or 0 (none adopters) and these act as dependent variable (Kelejian and Oates, 1989; Oritz, 1998; Gujarali, 1986).

By assuming that the response probability is linear in a set of parameters, the Logit model can be expressed as:

$\log (P / 1-P)=\beta_{0}+\beta_{1} x_{1}+\ldots+\beta_{20} x_{20}$

Where $\beta_{0}, \beta_{1} \ldots \beta_{20}$ denoted as estimated coefficients; $x_{1} \ldots . . x_{20}$ denoted the independent variables (age, education, family experience, household size, farm size, attendance of training, heard of IPM, 
Table 1. Demographic, socio-economic and institutional variables of cowpea farmers in Mubi zone.

\begin{tabular}{|c|c|c|c|c|c|c|}
\hline Variable & Category & Frequency & Percentage & Df & Chi square & Probability \\
\hline \multirow{4}{*}{ Age } & $20-30$ & 102 & 17 & \multirow{4}{*}{3} & \multirow{4}{*}{128.65} & \multirow{4}{*}{ ** } \\
\hline & $31-40$ & 261 & 43 & & & \\
\hline & $41-50$ & 167 & 27 & & & \\
\hline & $51>$ & 81 & 13 & & & \\
\hline \multirow{2}{*}{ Gender } & Male & 449 & 74 & \multirow{2}{*}{1} & \multirow{2}{*}{134} & \multirow{2}{*}{$\star \star \star *$} \\
\hline & Female & 162 & 26 & & & \\
\hline \multirow{5}{*}{ Educational attainment } & No formal education & 127 & 21 & \multirow{5}{*}{4} & \multirow{5}{*}{271.6} & \multirow{5}{*}{ ** } \\
\hline & Primary/Quranic & 267 & 44 & & & \\
\hline & Secondary school & 77 & 12 & & & \\
\hline & Diploma & 121 & 20 & & & \\
\hline & Degrees & 19 & 3 & & & \\
\hline \multirow{4}{*}{ Household size } & $1-5$ & 219 & 36 & \multirow{4}{*}{3} & \multirow{4}{*}{410.11} & \multirow{4}{*}{$* *$} \\
\hline & $6-10$ & 250 & 41 & & & \\
\hline & $11-15$ & 84 & 14 & & & \\
\hline & $>15$ & 58 & 9 & & & \\
\hline \multirow{6}{*}{ Farming experience in years } & $<10$ & 227 & 37 & \multirow{6}{*}{5} & \multirow{6}{*}{490.17} & \multirow{6}{*}{ ** } \\
\hline & $11-20$ & 195 & 32 & & & \\
\hline & $21-30$ & 133 & 23 & & & \\
\hline & $31-40$ & 39 & 6 & & & \\
\hline & $41-50$ & 15 & 1.5 & & & \\
\hline & $51>$ & 2 & 0.5 & & & \\
\hline \multirow{4}{*}{ Farm size } & $1-5 \mathrm{ha}$ & 342 & 75 & \multirow{4}{*}{3} & \multirow{4}{*}{234.32} & \multirow{4}{*}{ ** } \\
\hline & $6-10$ ha & 93 & 21 & & & \\
\hline & $11-15$ ha & 11 & 3 & & & \\
\hline & $16-20$ ha & 6 & 1 & & & \\
\hline \multirow{3}{*}{ Source of family labour } & Hired & 323 & 54 & \multirow{3}{*}{2} & \multirow{3}{*}{207.05} & \multirow{3}{*}{ ** } \\
\hline & Family labour & 246 & 40 & & & \\
\hline & Both & 42 & 6 & & & \\
\hline & ADP & 7 & 1 & & & \\
\hline & Ministry of Agriculture & 33 & 5 & & & \\
\hline Seed source & Open market & 300 & 49 & 5 & 58058 & * * \\
\hline seed source & Seed dealers & 13 & 2 & 0 & 500.50 & \\
\hline & Previous farming & 250 & 42 & & & \\
\hline & Friends & 8 & 1 & & & \\
\hline
\end{tabular}

membership of socio-cultural organization, extension services, access to loan, price of insecticides, dealers, extension advice, membership to organization, marital status, source of income, seed source, land preparation and land ownership, respectively), and $p$ denoted as probability.

The use of biopesticides was used as dependent variable. For these dependent variables decision to adopt any technology as a binary variable ( $1=$ use of insecticide; $0=$ otherwise) that measures the extent of adoption.

\section{RESULTS AND DISCUSSION}

Cowpea farmers whose age fell within the age group 31 to 40 years are in majority (Table 1 ). This implied that our respondents are young and of the middle age group. Our findings are similar to those presented by Oritz (1998) and Agwu (2001); they reported that young adult farmers have high aspirations to accept new technologies than 
older farmers who seem to be more satisfied with their traditional farming methods. However, Ikani et al. (1998) proposed that farmers who are older, have more years of farming experience in agricultural production, and more innovative. In contrast, Australian farmers within the age of 40 to 50 years adopted conservation technology compared to farmers in lower age group (Agwu, 2004). This investigation showed that cowpea production skewed to the male sex. Consistent with this result are previous reports. Sabo et al. (2009) among cotton farmers in Zones 1 and 2 of Adamawa State, and among vegetable farmers in Mubi zone (Sabo and Dia, 2009). On the other hand, high participation of women farmers compared to the men was recorded in the cultivation of Kalima variety of cowpea in Malawi (Masangano and Miles, 2004). However, women are actively involved in processing, storage and marketing of cowpea compared to men (Sabo et al., 2009). This trend of result may be associated with the custom or norms and possibly the religious beliefs of the respondents interviewed. The proportion $(44 \%)$ of the farmers with primary/quoranic education certificate was larger compared to those who had secondary school certificate/diploma/university degree. Educated farmers are supposed to be more efficient in combining resources through knowledge gained from information than non-educated farmers. Also, they are better able to process information and search for appropriate technologies to alleviate their production constraints (NAQAS, 2001).

A large percentage of our respondents are married (76\%); and household size of 6 to 10 was most frequent. This is associated with the desire to have access to farm labour at reduced cost. Cowpea producers are experienced in production and management of insect pests'. Farmers are aware of market and consumer preferences (seed colour, seed size and seeds devoid of holes and reduced pesticides and processing residues) (data not shown). Majority of the cowpea producers source for cowpea seeds from the open market (49\%); this category was closely followed by those who saved seeds from previous planting (42\%). Cowpea producers who sourced seeds from the Agricultural Development Projects might be interested in new varieties, while those who saved seeds from previous planting might have the intension to circumvent the cost of seed purchase and ensure purity. The inadequate participation of seed companies in commercialization of cowpea varieties led to the development of farmer - to - farmer seed system (Gujarati, 1995). The use of insecticides, fumigants, biopesticides and cultural practices are a few of the insect pests' management technologies developed by research and communicated to farmers as insect pests management technology (IPM), primarily to reduce damage caused by insect pests' during field planting and storage.

High proportion (98\%) of cowpea farmers used inorganic chemicals to control insect pests during field planting and storage (Table 2) compared to biopesticides. This trend is similar to those reported by Jackai and Adebayo (1997), Tamo et al. (1997) and Afun et al. (1991). It is important to note that insecticides have varying mode of activity, they are either narrow spectrum or broad spectrum activity. This is often associated with the selling price. Cowpea farmers who applied insecticides twice during the cowpea crop cycle accounted for $50 \%$ of the respondents. Those who applied insecticides three times during cowpea crop cycle accounted for $21 \%$ of the respondents. While those who sprayed once constituted $9 \%$ of the cowpea producers. Respondents who applied insecticides for a period of four times and over during the crop growth cycle summarized $21 \%$ of the cowpea farmers interviewed. The quantity of insecticides (liter) used by the cowpea farmers was dependent on the insect pest predominance, farm size, spraying regime (spraying intensity) and dilution ratio (water to insecticides). We observed that insecticides (liter) used by farmers per acre ranged between 1 and 3 L. Cowpea farmers who used $1 \mathrm{~L} /$ ha accounted for $57 \%$, and cowpea farmers who applied between 2 and $3 \mathrm{~L} / \mathrm{ha}$ accounted for 29 and $14 \%$, respectively. The foregoing is a pointer to an excessive use of insecticides by cowpea farmers, and an indication that cowpea producers do not adhere to recommended dilution rate of insecticides (20 $\mathrm{mls}$ into $10 \mathrm{~L}$ of water). Further, $75 \%$ of the cowpea farmers considered damage by insect pests serious at flowering after spraying, while $24 \%$ of the cowpea farmers indicated otherwise.

After spraying inorganic insecticides, $66 \%$ of cowpea producers reported that insect damage impacted negatively on seed yield and seed quality. This trend may be associated with adulterated inorganic chemical or a wrong choice of insecticides. This investigation sought to understand how long it takes for insects to appear on cowpea plant after spraying. Responses diverged between 1 and 5 weeks after spraying. Farmers who indicated that it took 1,2 and 3 weeks to see insects on cowpea after spraying accounted for 16, 22 and 18\%, respectively. However, farmers who indicated 4 and 5 weeks accounted for 33 and $12 \%$, respectively. The Chisquare goodness of fit for this category was significant $(P<0.05)$. This implied that these categories differed. The resurgence of insects on cowpea plants is dependent on whether the insecticide is a contact or systemic, narrow or broad spectrum approach and the active ingredient. However, a rainfall between 5 to 45 min after a spray of insecticides will affect the efficacy of the insecticide. Therefore, farmers are advised to spray after rainfall or whenever the sky is not cloudy.

The study showed that a large proportion $(71 \%)$ of cowpea farmers indicated that the cost of insecticides was extremely not important during purchase. But emphasis on the dealer (76\%) was high during purchase of insecticides in the open market. The most limiting constraints to cowpea production in Mubi zone included 
Table 2. Distribution of respondents by use of insecticides and effectiveness of these chemical.

\begin{tabular}{|c|c|c|c|c|c|c|}
\hline Character & Category & Frequency & Percentage & Df & Chi square & Probability \\
\hline $\begin{array}{l}\text { Type pesticides used in } \\
\text { control of insect pests }\end{array}$ & $\begin{array}{l}\text { Inorganic insecticides } \\
\text { Organic chemical }\end{array}$ & $\begin{array}{c}600 \\
11\end{array}$ & $\begin{array}{c}98 \\
2\end{array}$ & 1 & 564.21 & $* *$ \\
\hline \multirow{9}{*}{$\begin{array}{l}\text { Types of insecticides used } \\
\text { in cowpea storage }\end{array}$} & Karate & 382 & 63 & \multirow{9}{*}{8} & \multirow{9}{*}{1566.11} & \multirow{9}{*}{$* *$} \\
\hline & Decis & 59 & 10 & & & \\
\hline & Sherpa plus & 14 & 5 & & & \\
\hline & Nuvacron & 94 & 2 & & & \\
\hline & DD Force & 20 & 12 & & & \\
\hline & DDT & 17 & 3 & & & \\
\hline & Perfekthion & 5 & 3 & & & \\
\hline & Upper cott & 5 & 1.3 & & & \\
\hline & Super cott & 4 & 0.7 & & & \\
\hline \multirow{6}{*}{$\begin{array}{l}\text { Period (time) of application } \\
\text { of insecticides in one cycle } \\
\text { of cowpea planting }\end{array}$} & Once & 58 & 9 & \multirow{6}{*}{5} & \multirow{6}{*}{555.96} & \multirow{6}{*}{$* *$} \\
\hline & Twice & 120 & 50 & & & \\
\hline & Thrice & 308 & 21 & & & \\
\hline & Four times & 66 & 11 & & & \\
\hline & Five times & 22 & 4 & & & \\
\hline & Six times & 37 & 6 & & & \\
\hline \multirow{2}{*}{$\begin{array}{ll}\text { Severity of insect damage } \\
\text { at flowering before } \\
\text { spraying }\end{array}$} & Yes & 511 & 83 & \multirow{2}{*}{1} & \multirow{2}{*}{74.39} & \multirow{2}{*}{ ** } \\
\hline & No & 100 & 17 & & & \\
\hline \multirow{3}{*}{$\begin{array}{l}\text { Quantity of insecticides } \\
\text { (litre) used/ha }\end{array}$} & $1 \mathrm{~L}$ & 256 & 57 & \multirow{3}{*}{2} & \multirow{3}{*}{126.72} & \multirow{3}{*}{$* *$} \\
\hline & $2 \mathrm{~L}$ & 133 & 29 & & & \\
\hline & $3 \mathrm{~L}$ & 63 & 14 & & & \\
\hline \multirow{2}{*}{$\begin{array}{l}\text { Presence of insect after } \\
\text { spraying at flowering }\end{array}$} & No & 147 & 24 & \multirow{2}{*}{1} & \multirow{2}{*}{55.23} & \multirow{2}{*}{$* *$} \\
\hline & Yes & 464 & 75 & & & \\
\hline \multirow{2}{*}{$\begin{array}{l}\text { Insect damage serious } \\
\text { after spraying }\end{array}$} & Yes & 404 & 66 & \multirow{2}{*}{1} & \multirow{2}{*}{4.28} & \multirow{2}{*}{$* *$} \\
\hline & No & 207 & 34 & & & \\
\hline & 1 week & 98 & 16 & & & \\
\hline Time interval for & 2 weeks & 132 & 22 & & & ** \\
\hline appearance of insects & 3 weeks & 105 & 18 & 4 & 8.97 & \\
\hline & 4 weeks & 204 & 33 & & & \\
\hline & 5 weeks & 72 & 12 & & & \\
\hline Consideration of the & Extremely important & 175 & 29 & & & \\
\hline $\begin{array}{l}\text { dealer during purchase of } \\
\text { insecticides }\end{array}$ & Not important & 436 & 71 & 1 & 111.49 & ** \\
\hline Consideration of price & Extremely important & 542 & 76 & & & \\
\hline $\begin{array}{l}\text { during purchase of } \\
\text { insecticides }\end{array}$ & Very important & 69 & 11 & 1 & 401.75 & ** \\
\hline
\end{tabular}

${ }^{* *} \mathrm{P}<0.01$ = significant at $1 \%$ level of probability.

problems associated with diseases, insect pests attack, high cost of insecticides, high cost of land preparation and poor soil fertility (Table 3 ). These variables recorded high mean score, which ranged between 3.15 and 3. 39 . In contrast, demographic variables (age, sex and religion) recorded mean score less than 2.0. This corresponds to 
Table 3. Constraints expressed by extent to which factors limit cowpea production in Mubi zone.

\begin{tabular}{|c|c|c|c|c|c|c|c|}
\hline Technology & $\begin{array}{l}\text { Great } \\
\text { extent }\end{array}$ & $\begin{array}{l}\text { Some } \\
\text { extent }\end{array}$ & $\begin{array}{l}\text { Little } \\
\text { extent }\end{array}$ & $\begin{array}{c}\text { No } \\
\text { extent }\end{array}$ & $\begin{array}{c}\text { Total number } \\
\text { of farmers }\end{array}$ & $\begin{array}{l}\text { Mean } \\
\text { score }\end{array}$ & Rank \\
\hline Non availability of seeds & $203(1.33)$ & $204(1.00)$ & $90(0.44)$ & $115(0.19)$ & 611 & 2.96 & 8 \\
\hline High cost of land & $270(1.77)$ & $203(1.00)$ & $63(0.31)$ & $75(0.12)$ & 611 & 3.20 & 6 \\
\hline Poor soil fertility & $304(1.99)$ & $211(1.04)$ & $50(0.16)$ & $46(0.08)$ & 611 & 3.27 & 4 \\
\hline Problems of insect pests & $286(1.87)$ & $209(1.03)$ & $97(0.48)$ & $19(0.03)$ & 611 & 3.41 & 2 \\
\hline Problem of diseases & $297(2.66)$ & $200(0.98)$ & $100(0.33)$ & $14(0.02)$ & 611 & 3.93 & 1 \\
\hline Cost of buying insecticides & $298(0.95)$ & $221(1.09)$ & $50(0.25)$ & $42(0.07)$ & 611 & 3.36 & 3 \\
\hline Land size & $224(1.47)$ & $184(0.90)$ & $101(0.33)$ & $100(0.16)$ & 611 & 2.86 & 9 \\
\hline Educational level & $206(1.35)$ & $185(0.91)$ & $120(0.39)$ & $100(0.16)$ & 611 & 2.81 & 10 \\
\hline Religion & $57(0.35)$ & $54(0.27)$ & $200(0.33)$ & $300(0.49)$ & 611 & 1.44 & 14 \\
\hline Sex & $67(0.44)$ & $53(0.26)$ & $148(0.48)$ & $343(0.56)$ & 611 & 1.74 & 13 \\
\hline Age & $50(0.33)$ & $77(0.38)$ & $172(0.57)$ & $301(0.49)$ & 611 & 1.77 & 12 \\
\hline High cost of land rent & $150(0.98)$ & $242(1.19)$ & $119(0.39)$ & $100(0.16)$ & 611 & 2.72 & 11 \\
\hline High cost of land preparation & $341(2.23)$ & $124(0.61)$ & $100(0.33)$ & $28(0.05)$ & 611 & 3.22 & 5 \\
\hline Gender in respect of land ownership & $291(1.91)$ & $168(0.82)$ & $100(0.33)$ & $52(0.09)$ & 611 & 3.15 & 7 \\
\hline
\end{tabular}

Numbers in parenthesis are calculated scores from each category. Mean score $>2.00$ was effective; mean score $<2.00$ was ineffective.

Table 4. Extent of which these socio economic variables and institutional variables limit adoption of inorganic insecticides.

\begin{tabular}{|c|c|c|c|c|c|c|c|}
\hline Variable & $\begin{array}{c}\text { Great } \\
\text { extent }\end{array}$ & $\begin{array}{l}\text { Some } \\
\text { extent }\end{array}$ & $\begin{array}{l}\text { Little } \\
\text { extent }\end{array}$ & $\begin{array}{c}\text { No } \\
\text { extent }\end{array}$ & Total & Score & Rank \\
\hline Expensive insecticides & $397(2.60)$ & $149(0.73)$ & $43(0.14)$ & $22(0.04)$ & 611 & 3.51 & 1 \\
\hline Complex insect management technologies & $260(1.70)$ & $249(1.20)$ & $74(0.24)$ & $15(0.03)$ & 611 & 3.17 & \\
\hline Illiteracy & $386(2.52)$ & $124(0.61)$ & $57(0.19)$ & $50(0.08)$ & 611 & 3.40 & 5 \\
\hline Expensive knapsacks & $102(0.81)$ & $333(1.64)$ & $129(0.42)$ & $16(0.03)$ & 611 & 2.92 & \\
\hline Adulteration & $272(1.78)$ & $223(1.09)$ & $100(0.33)$ & $16(0.03)$ & 611 & 3.23 & \\
\hline Interpretation of tech & $28(0.18)$ & $74(0.36)$ & $246(0.81)$ & $283(0.38)$ & 611 & 1.73 & \\
\hline Health hazards & $367(2.40)$ & $194(0.95)$ & $42(0.14)$ & $8(0.01)$ & 611 & 3.50 & 2 \\
\hline High cost of control methods & $239(2.22)$ & $210(1.03)$ & $44(0.14)$ & $18(0.03)$ & 611 & 3.42 & 4 \\
\hline Labour & $226(1.48)$ & $200(0.98)$ & $140(0.40)$ & $45(0.07)$ & 611 & 2.99 & \\
\hline Farm size & $386(2.52)$ & $124(0.61)$ & $100(0.33)$ & $7(0.000)$ & 611 & 3.46 & 3 \\
\hline Family size & $87(0.57)$ & $79(0.39)$ & $200(0.65)$ & $245(0.40)$ & 611 & 2.01 & \\
\hline Age & $26(0.17)$ & $67(0.33)$ & $288(0.94)$ & $240(0.39)$ & 611 & 1.80 & \\
\hline
\end{tabular}

Numbers in parenthesis are calculated scores from each category. Mean score $>2.00$ was of great extent; mean score $<2.00$ was least extent.

little impact of these variables on cowpea production in Mubi zone. Result presented are similar to those reported by Agwu (2004) among cowpea farmers in Bauchi and Gombe States; Sabo and Dia (2009) among vegetable farmers in Mubi zone and Sabo et al. (2009) among cotton farmers in the cotton belt of Adamawa State, Nigeria. The cowpea producers indicated that high seed yield is consequent upon high yielding varieties and use of insecticides. Use of insecticides is constrained by high cost of insecticides and health hazards on the farmers and his household, and environmental pollution (Table 4) associated with use and misuse of inorganic insecticides. Excessive use of insecticides (spraying more than four times) could lead to contamination of the land, water, soil and the environment. Another concern with pesticides use is lack of safe handling procedures. Farmers eat, drink or smoke without washing after spraying. Due to high cost of spraying kit and ignorance, spraying is done without the use of nose mask and wearing of farm overall. Further, farm size, high cost of control methods and illiteracy proved important in limiting adoption of insect pests' management techniques. Though, these variables limit adoption, farmers are increasingly engaged in the use of insecticides for seed yields.

The result of analysis of adoption of inorganic chemicals using logistic regression (Table 5) showed that statistical $\beta$ for example -2Log $L$ was negative, log likelihood, Wald and Score were positive and significant 
Table 5. Determinants of adoption of inorganic insecticides using logistic regression model.

\begin{tabular}{lccccc}
\hline Variable & Df & B & SE & Chi square & Probability \\
\hline Intercept & 1 & -2.24 & 2.78 & 0.65 & 0.41 \\
Age & 1 & 0.09 & 0.03 & 5.49 & $0.02^{*}$ \\
Education & 1 & -0.31 & 0.21 & 2.22 & 0.14 \\
Gender & 1 & 0.32 & 0.49 & 0.42 & 0.52 \\
Marital status & 1 & 0.72 & 0.48 & 2.24 & 0.13 \\
Household size & 1 & -0.06 & 0.20 & 0.08 & 0.77 \\
Primary occupation & 1 & 0.02 & 0.14 & 0.02 & 0.88 \\
Farm size & 1 & 0.16 & 0.33 & 0.22 & 0.63 \\
Source of farm labour & 1 & 0.16 & 0.33 & 0.22 & 0.63 \\
Educational attainment & 1 & 0.98 & 0.50 & 3.89 & $0.05^{*}$ \\
Land preparation & 1 & -1.40 & 0.52 & 7.14 & 0.07 \\
Extension agent & 1 & 0.10 & 1.05 & 0.009 & 0.92 \\
Extension meeting & 1 & 0.27 & 0.38 & 0.48 & 0.49 \\
Membership of socio cultural organization & 1 & 1.27 & 0.60 & 4.48 & $0.03^{*}$ \\
Experience & 1 & -0.05 & 0.04 & 1.49 & 0.22 \\
Attendance of training & 1 & -0.77 & 0.58 & 1.80 & 0.18 \\
Land ownership & 1 & -0.53 & 0.64 & 0.69 & 0.41 \\
Access to loan & 1 & -0.81 & 1.05 & 0.60 & 0.44 \\
Importance of cost & 1 & -0.61 & 0.23 & 4.83 & 0.12 \\
Information source & 1 & 0.50 & 0.20 & 6.46 & $0.01^{* *}$ \\
Consideration of the dealer during purchase & 1 & 0.92 & 0.17 & 27.52 & $0.01^{* *}$ \\
- 2 Log L & & & & 805 & \\
Wald & & & & $61.01^{* * *}$ & \\
Likelihood & & & & $108.57^{* * *}$ & \\
\hline Sourc:Fin
\end{tabular}

Source: Field survey $(2008-2009)$. ${ }^{*} \mathrm{P}<0.05$, ${ }^{* *} \mathrm{P}<0.01$, ${ }^{* *} \mathrm{P}<0.001$ level of probability.

$(P<0.0001)$. However, of the 21 independent variables examined in the regression procedure, 12 variables turned out to have positive estimates, while 9 variables were negative. This implied that most of the farmers have adopted use of inorganic insecticides as a requirement for high yield. The logistic model showed significant likelihood that age $(\beta=0.09, P<0.05)$, educational attainment $(\beta=0.98, P<0.05)$, membership of socio cultural organizations $(\beta=1.27, P<0.05)$, information source on insecticides $(\beta=0.50, \quad P<0.01)$ and consideration of the dealer during purchase $(\beta=0.92$, $\mathrm{P}<0.01)$ influenced adoption of inorganic insecticides. These variables recorded positive $\beta$ values in the adoption of inorganic insecticides use and could be complementary to adoption of insecticide use. This study demonstrated that age of the respondents had positive and significant relationship with adoption of inorganic insecticide use. This implied that as farmers' increases in age; there is the likelihood of a steady increase in the use of inorganic chemicals. Membership of socio cultural organization was positively related to adoption of insecticides, this mirrored previous report of Agwu (2001) and Sabo and Dia (2009), who indicated a significant influence of membership of socio-cultural groups on adoption.
In addition, extension has been identified as a way of building human capital of the farmers by exposing them to information that increase income and reduces uncertainties (Feder et al., 2005). In this study, accessibility to information is related to adoption of insecticides. Consideration of the insecticide dealer was related to adoption of technology. The implied reliability of the source (insecticides marketer) and has a great influence on adoption of inorganic insecticides, as long as the end user perceive the source as reliable for non adulterated insecticides. Statistical parameters for this analysis indicated that likelihood ratio, score and Wald estimates are highly significant and positive. -2 Log estimate was high and positive. The adoption of spraying regime requires monitoring the growth stages and build up of insects on the farm and applying a selective or a broad spectrum insecticide. On the other hand, farmers are advised to have a maximum four spraying regime throughout the growth period for the crop; at times, spraying should be done on sighting insect on the farm. Our respondents affirmed that spraying broad spectrum insecticides during growth stages was convenient (data not shown), though broad spectrum insecticides are expensive compared to selective insecticides. The result of the logistic regression analysis of independent 
Table 6. Determinants of adoption of spraying regime using logistic regression analysis.

\begin{tabular}{lccccc}
\hline Variables & Df & B & Standard error & Chi square & Probability \\
\hline Intercept & 1 & 2.97 & 1.34 & 4.90 & $0.02^{*}$ \\
Age & 1 & 0.02 & 0.01 & 0.69 & 0.40 \\
Education & 1 & 0.07 & 0.10 & 0.69 & 0.40 \\
Sex & 1 & 0.07 & 0.21 & 0.10 & 0.72 \\
Marital status & 1 & 0.06 & 0.22 & 0.07 & 0.79 \\
House hold size & 1 & 0.009 & 0.07 & 0.01 & 0.90 \\
Occupation & 1 & -0.09 & 0.06 & 2.57 & 0.10 \\
Farm size & 1 & -0.03 & 0.04 & 0.77 & 0.38 \\
Source of farm labour & 1 & -0.07 & 0.14 & 0.21 & 0.64 \\
Seed source & 1 & -0.19 & 0.08 & 5.76 & $0.01^{* *}$ \\
Seed treatment & 1 & -0.42 & 0.20 & 4.25 & $0.04^{*}$ \\
Seed treatment & 1 & -0.05 & 0.06 & 0.87 & 0.35 \\
Land preparation & 1 & -0.33 & 0.31 & 1.13 & 0.28 \\
Extension contact & 1 & -0.94 & 0.51 & 3.76 & $0.05^{*}$ \\
Frequency of extension contact & 1 & -0.42 & 0.19 & 4,77 & $0.02^{*}$ \\
Membership of an organization & 1 & -0.26 & 0.22 & 1.46 & 0.22 \\
Farming experience & 1 & -0.03 & 0.01 & 3.58 & $0.05^{*}$ \\
Attendance of training & 1 & 0.21 & 0.29 & 0.51 & 0.47 \\
Land ownership & 1 & -0.82 & 0.29 & 7.97 & $0.005^{* *}$ \\
Access to loan & 1 & 0.51 & 0.49 & 1.07 & 0.30 \\
Training & 1 & -0.31 & 0.11 & 7.17 & $0.007^{* *}$ \\
Implication of cost & 1 & 0.07 & 0.05 & 1.65 & 0.19 \\
Consideration of the dealer & 1 & 0.11 & 0.07 & 2.36 & 0.12 \\
-2 Log L & & & & 798.47 & \\
Likelihood ratio & & & & $44.74^{* *}$ & \\
Wald & & & & & \\
\hline Souce: Field surey & & & & & \\
\hline
\end{tabular}

Source: Field survey (2008-2009). ${ }^{*} \mathrm{P}<0.05,{ }^{* *} \mathrm{P}<0.01$ level of probability.

variables and adoption of spraying regime (Table 6) showed that the log likelihood estimates was positive and the Chi-square value, Score and Wald estimates were highly significant $(P<0.001)$. Of the 22 independent variables examined, six independent variables [seed source $(\beta=-0.19, P<0.01)$, seed treatment $(\beta=-0.42$, $P<0.05)$, frequency of extension contacts $(\beta=-0.42$, $P<0.05)$, farming experience $(\beta=-0.03, P<0.05)$, land ownership $(\beta=-0.82, P<0.01)$ and access to training $(\beta=$ -0.31, $P<0.01$ ) recorded significant relationship with adoption of spraying regime by cowpea farmers in Mubi zone. In the same vein, these variables recorded positive estimates $(\beta)$ in the probability to adoption of insecticides use and could be complementary to adoption of this technology.

A significant probability of seed source and seed treatment on adoption of spraying regime could be explained as a complementary association between seed treatment chemicals and seed source. However, farmers are aware that their varieties are susceptible to insect pests' and other soil borne diseases therefore, the use of seed treatment chemical. This study demonstrated that extension contact and the frequency of extension contact recorded positive and significant relationship with adoption of spraying regime. In addition, farming experience, land ownership and implication of cost during purchase of insecticides are positively related to adoption of spraying time. Several authors have explained that farming experience, land ownership, implication of cost to be associated with adoption of innovation (Saginga et al., 1999; Matteson et al., 1984). These independent variables are positively related to adoption of spraying regime as evaluated among cowpea farmers in Mubi zone. Similarly, membership of socio - cultural group significantly influence adoption of spraying regime, this correspond with findings of Ajala (1992) and Ikani (1998). Cowpea producers in Mubi zone are well informed about the menace of insect pests on cowpea in the absence of insecticide spray (inorganic insecticides). The choice of insecticides among cowpea producers was influenced largely by who the dealer is. While continuous use of inorganic insecticides was influenced by age, literacy, available source and membership of socio - cultural organization. 
The practice of spraying regime among cowpea growers was contingent upon extension contacts and experience in cowpea farming. The high cost associated with use of inorganic insecticides limit its use; this may promote use of adulterated insecticides. Also, cowpea growers are knowledgeable of the health hazard associated with the use of inorganic insecticides. The availability of resistant varieties and biopesticides will reduce huge cost of buying insecticides and minimize health and environmental hazards.

\section{REFERENCES}

Adamawa State Extension Service (1990). Yearly Bulletin.

Adebayo K (1997). Communication in Agriculture. Abeokuta Greenlinks International, pp. 53-54.

Afun JVK, Jackai LEN, Hodgson CJ (1991). Calendar and monitored insecticide application for the control of cowpea pests. Crop Prot. 10:363-370.

Agwu AE (2001). Adoption of improved cowpea production techniques by farmers in North Eastern savannah zone of Nigeria. Privatization and Commercialization of extension service delivery in Nigeria: Problems and Prospects. T. A Olowu (ed) proceedings of the $7^{\text {th }}$ Annual Conference of the Agricultural Extension Society of Nigeria, $19^{\text {th }}-22^{\text {nd }}$ August 2001, pp. 74-81.

Agwu AE (2004).Factors affecting adoption of improved cowpea production technologies in Nigeria. J. Int. Agric. Ext. Educ. 11(1):8188.

Ajala AA (1992). Factors Associated with adoption of improved practices by Goat producers in Southeastern Nigeria. Research monograph Department of Agricultural Extension University of Nigeria, Nsukka. p. 5.

Alghali AM (1991). Studies on cowpea farming practices in Nigeria, with emphasis on insect pest control. Trop. Pest Manage. 37:71-74.

Amemiya T (1981). Qualitative response models: A survey. J. Econ. Lit., 19:1483-1536.

FAO (1961). Agricultural and Horticultural seeds, their production, control and distributions. Food Agric. Org. Stud. 55:531.

FAO (1998). Knowledge and information for food security in Africa from traditional media to the internet. Communication for Development Group. Extension Education and Communication Service (SDRE), FAO Research and Training Division, Rome, Italy.

Feder G, Just RE, Zilberman D (2005). Adoption of Agricultural Innovations in Developing Countries: A survey, Econ. Develop. Cult. Change 33(2):119-233.

Gujarati DN (1995). Basic Econometrics. $2^{\text {nd }}$ Edition, McGraw-Hill Inc. New York. pp. 32-44.

Ikani El, Umar M, Jegede OC (1998). Study of extent of adoption of cockerel exchange technology (CET) by rural farmers in Adamawa state of Nigeria. Proceedings of the silver Anniversary Conference of the Nigeria Society for Animal Production (NSAP, 21-26 March 1998).

Jackai LEN, Daoust RA (1986). Insect pests of cowpea. Annu. Rev. Entomol. 31:95-119.

Jackai LEN, Singh SR, Raheja AK, Wiedijk F (1985). Recent trends in the control of cowpea pests in Africa. Pages 233-243 in cowpea research, production and utilization, edited by S. R. Singh and K. O. Rachie. John Wiley and Sons, Chichester, UK.
Jackai, LEN, Inang, EE, Nwobi P (1993). The potential for controlling post-flowering pests of cowpea, Vigna unguiculata Walp. I. Using neem, Azadirachta indica (A. Juss). Trop. Pest Manage. 38(1):56-60.

Jackai LEN, Adalla CB (1997). Pest management practices in cowpea: A Review. Pages 240-258 in Advances in cowpea research, edited by B. B. Singh, D. R. Mohan Raj, K.E. Dashiell, and L. E. N. Jackai, Sayce Publishing, Devon, UK.

Kelejian HH, Oates WE (1989). Introduction to Econometrics. Principles and applications. Published by Harper and Row. New York. p. 367.

Masangano CM, Miles CA (2004). Factors influencing farmers' adoption of kalima Bean (Phaseolus vulgaris L.) variety in Malawi. J. Sustain. Agric. 24(2):117-129.

Matteson PC, Altieri MA, Gagne WC (1984). Modification of small farmer practices for better management. Annu. Rev. Entomol. 29:383-402.

Nigeria Agricultural Question and Answer Services (NAQAS) (2001) Annual Review, Institution for Agricultural Research, ABU Zaria, $p$. 12

Oritiz R (1998). Cowpea from Nigeria: A silent Revolution outlook. Agriculture 27(2):125-128.

Rachie KO (1985). Cowpea research, production and utilization, In B. B. Singh, D. R. Mohan Raj, K. E. Dashiell and L. E. N. Jackai (eds), Advances in Cowpea Research, Syace Publishing, Devon, UK. pp 326-333.

Sabo E, Dia YZ (2009). Awareness and effectiveness of vegetable technology information packages by vegetable farmers in Adamawa State, Nigeria. Afr. J. Agric. Res. 4(2):065-070.

Sabo E, Dia YZ, Pur JT (2009). An evaluation of involvement of youths in agriculture and adoption of agricultural technology information. Agric. J. 2(5):627-626.

Saginga PC, Adesina AA, Manyoug VM, Ottle O, Dashiel KE (1999). Social impact of soybeans in Nigeria's Southern Guinea Savanna. Printed by IITA and Meg-Communication Network, Nigeria. p. 32.

Tamo M, Bottenberg H, Arodokoun D, Adeoti R (1997). The feasibility of classical biological control of two major cowpea insect pests. In Advances in cowpea research, edited B. B. Singh, D. R. Mohan Raj, K. E. Dashiell and L. E. N. Jackai (eds), Advances in Cowpea Research, Syace Publishing, Devon, UK, pp. 249-265.

Tobin J (1958). Estimation of relationship with limited variable. Econometrica 26:24-36.

Wooldridge JM (2001). Introductory Econometrics: A modern approach to E. Michigan State University, West Division Thomson, South Western, Australian. p. 863. 